\title{
Mortality at 9 years in alcohol-dependence: The respective roles of alcohol, tobacco, and vulnerability genes
}

\author{
Mathias Wohl $^{1,2}$, Laetitia Sirolli ${ }^{2}$, Lucia Romo ${ }^{2}$, Philippe Batel ${ }^{1}$, Claudette Boni ${ }^{1}$, Philip Gorwood ${ }^{1,3}$ \\ ${ }^{1}$ INSERM U894, Centre de Psychiatrie et Neuroscience, Paris, France \\ ${ }^{2}$ AP-HP, CHU Louis Mourier, Service de Psychiatrie, Colombes, France \\ ${ }^{3} \mathrm{CMME}$, Centre Hospitalier Sainte Anne, Paris, France \\ Email: P.GORWOOD@ch-sainte-anne.fr
}

Received 6 April 2012; revised 30 April 2012; accepted 12 May 2012

\section{ABSTRACT}

Aims: Different vulnerability genes have been proposed in alcohol dependence, but replications are sparse, probably due to 1) phenotypical heterogeneity and 2) difficulties to rely on reliable definition of the correct phenotype. Indeed, specific subgroups of patients may be more directly concerned with some vulnerability genes, the actions of these genes being more directly related to their function. We postulated that three potential vulnerability genes, that were at least twice associated with alcohol dependence, influence the extreme of the severity of alcohol dependence, i.e. mortality, through traits with which they were previously associated, namely impulsivity and antisocial personality disorder and the 5-HT1B gene, suicide attempt and the short allele of 5-HTTLPR, and addictive disorder co-morbidity and the DRD2 gene. Methods: We analysed the survival status of a male alcohol-dependent sample $(n=126)$ recruited 9 years before, and could compare 61 surviving patients to 41 patients who died during this period (representing $81.0 \%$ of the initial sample). Results: The main clinical characteristic that was associated with an increased mortality rate was a larger cumulative tobacco use (pack-years). We also found that the $C$ allele of the 5-HT1b was the only one in excess in the non-surviving patients. Contrary to our hypothesis, impulsivity and antisocial personality disorder were not explaining the role of this gene. Conclusions: Even if there is a significant involvement of the 5HT1B C allele, no intermediate phenotype was detected in our sample. The relatively short delay of 9 years and the somewhat old age at baseline of our patients could have limited the influence of psychiatric comorbidity or the specificities of alcohol dependence, explaining why the only detected co-factor was tobacco consumption. Tobacco dependence is therefore the main factor to explain mortality within the first decade, and the effect of this co-morbid condi- tion is not explained by three vulnerability genes previously associated to alcohol dependence.

Keywords: Addiction; Survival; Outcome; Serotonin; Dopamine; Pack Years; Genetics

\section{INTRODUCTION}

Alcohol dependence has a dramatic mortality rate [1]. A follow-up of 100 women with alcohol dependence showed a 1) four times increased of mortality rate after 11 years; 2) that the majority of these deaths were directly or indirectly related to alcohol; 3) and that some variables such as older age at index, young age at onset of alcoholism and antisocial personality were significant predictors of such outcome [2].

Alcohol dependence is also frequently associated with other psychiatric disorders, such as antisocial personality, attention deficit-hyperactivity, mood or schizophrenia disorders $[3,4]$. Such co-morbidity could further deteriorate the survival prognosis, as in a study based on 500 outpatients, the presence of one of these psychiatric disorders increased by two the mortality rate at seven years, when compared with the general population [5]. Epidemiological data also show a high correlation between alcohol and cigarette consumptions. The prevalence of smoking is close to three times higher in alcoholic patients compared to general population [6]. Ninety percent of alcoholic patients are smokers [7], the prevalence of alcoholism reaching 10 times higher among smokers than nonsmokers [8]. These risks factors have been shown to interact to modify the global prognosis, as for example tobacco smoking enhances ethanol induced pancreatic injury [9].

In a male alcohol dependent sample, Powell et al. (1998) identified as survival predictors at 10 to 14 years the age at intake hospitalization, alcoholism severity, and antisocial personality disorder [10]. Such increase of mortality rate associated with psychiatric diagnosis does 
not seem to be entirely caused by the toxic effect of ethanol as psychiatric diseases are highly predictive of unnatural death [11]. This co-morbidity seems to be so important, than in a 15 years follow-up realized in substance abusers, psychiatric status was predictive of mortality, but abstinence at 5 years was not [12].

Genes might also be part of these complex risk factors. Berggren et al., (2010) have found a significant association of the Taq I A1 alelle of DRD2 gene with mortality over a 10-year period in a sample of 366 alcoholdependent individuals [13]. Biological, environmental and genetic factors may therefore interact to determine disease risk and outcome. The role of genes in mortality could be of different origins.

Firstly, genetic polymorphisms could be associated to higher level of vulnerability when exposed to a certain risk factor (gene $\times$ environment interaction) [14]. For a given level of consumption, some genotypes were indeed associated with outcome and mortality of alcoholic liver diseases [15,16] or tumorigenesis [17]. Another study found that lipid abnormalities are influenced by alcohol intake, presence of tobacco dependence, body mass index but also Apolipoprotein E genotype [18].

Secondly, genes might substantially influence the cumulative quantity of smoked tobacco [19] or of drunken alcohol [20], for example because of decreased initial level of response to alcohol, i.e. an increased initial tolerance [21,22].

Thirdly, in accordance with twin studies, genetic vulnerability may be shared by addictive disorder and impulsive behaviours [23]. Such impulsive phenotype may impact the type of consumption and the psychiatric comorbidity (such as antisocial personality), both factors being associated with a more pejorative prognosis of substance abuse (gene-environment additive effect). According to this hypothesis of shared genetic vulnerability for the different addictive disorders, the A1 allele of DRD2 was significantly more frequent in alcoholic patients with other substance dependencies [24], and was even proposed to explain a reward deficiency syndrome $[25,26]$.

Because of the role of alcohol dependence on the mortality prognosis, and the potential role of some genotypes, we studied mortality risk, taking into account initial level of dependence severity, psychiatric co-morbidity, and some vulnerability genes we already found associated (in this population) with alcohol dependence or related phenotypes. We therefore analysed the genetic influence on mortality in a male alcoholic population already studied with a transversal approach, for polymorphisms of the 5HT1B gene [27], 5-HTTLPR [28] and DRD2 gene [24].

We made the hypothesis that part of the mortality at nine years is explained by severity of alcohol depend- ence or addictive co-morbidity and vulnerability genes. Our main hypothesis is that genes that were previously associated with alcohol-dependence (or related phenotypes) are influencing the risk of death because of more specifically associated features, whether it is by comorbid antisocial personality disorder (with the GG genotype of the 5-HT1b gene), addictive co-morbidity (with the A1 allele of the DRD2 gene) or associated suicidal attempts (with the short allele of the 5-HTT gene).

\section{METHODS}

We previously recruited 126 male alcohol dependent patients from two general hospitals specialized in the treatment of alcoholism, in Paris and suburbs between March 1993 and April 1995, as detailed elsewhere [28]. Inclusion criteria consisted of DSM-III-R criteria of alcohol-dependence, and no co-morbid dementia or schizophrenia. The lifetime psychiatric and addictive diagnoses were made by face-to-face interview by senior psychiatrists (PG, PB) with the Diagnostic Interview for Genetic Studies (D.I.G.S.) [29]. In 2004, i.e. 9 years after the last inclusion, using hospital files, we contacted the patients themselves (66\%), and then, if not possible, a core family member $(7 \%)$ or the physician in charge $(9 \%)$ to establish the survival status. Furthermore, a letter was sent to each municipal corporation (100\%) of the town where the patients were born. This town hall organisation is in charge of a file containing all dates of birth and death of the citizens born in this town. Despite these searches, 24 patients (19\%) were not found and no valid information was given from the municipal corporation. We therefore based the analyses on $81 \%$ of the initial sample $(\mathrm{N}=102)$.

With this sample of 102 patients, and for an expected frequency of the studied alleles ranging between 22\% and $70 \%$ (the frequency we already observed in the alcohol dependent patients), a $20.5 \%$ of difference between survivors and non-survivors is required to show a significant difference, with an $\alpha$-risk of $5 \%$ and a $\beta$ power of $90 \%$.

The study protocol had been approved by the institutional review board at each institution, according to the code of Ethics of the World Medical Association (Declaration of Helsinki). Written informed consent was obtained from all participants.

The main characteristics of the followed-up sample ( $\mathrm{N}$ $=102$ ) and the rest of the initial sample are described in Table 1. The part of the sample for which the vital status was detected at 9 years was mainly comparable to the rest of the lost sample, apart from a tendency for less cumulative exposition to tobacco smoking $(\mathrm{t}=1.69, \mathrm{p}=$ $0.09)$ and an older age at inclusion $(\mathrm{t}=2.71, \mathrm{p}=0.008)$. 
Taq1 polymorphism of the DRD2 gene, 5-HTTLPR polymorphism, G861C 5-HT1b receptor gene polymorphism were compared in the two groups of patients with known vital status. These three genetic polymorphisms were previously analysed, according to their original report [30-32]. The Hardy Weinberg equilibrium was respected for these three markers on the sample tested herein $\left(\chi^{2}=0.31, \mathrm{df}=1, \mathrm{p}=0.58 ; \chi^{2}=0.22, \mathrm{df}=1\right.$, $\mathrm{p}=0.64$ and $\chi^{2}=0.47, \mathrm{df}=1, \mathrm{p}=0.49$ respectively).

Surviving individuals were compared to deceased ones according to clinical features and genotype, using $\chi^{2}$ tests for categorical measures, and Student $t$ test for quantitative ones. To detect any interaction between vulnerability genes and their potentially related phenotype to explain mortality at 9 years, a logistic regression test was used. The depending variable was being alive or dead at 9 years, and the explaining variables were the three previously involved genotypes (A1 allele of the DRD2 gene, presence of the short allele of the 5-HTT gene and GG genotype of the 5-HT1b gene) and their three associated phenotypes (other substance dependencies, suicidal attempts, and antisocial personality disorder, respectively). Default $\mathrm{p}$-values for stepwise entry $(\mathrm{p}=0.10)$, and removal $(\mathrm{p}=0.15)$ of predictors into the logistic model were retained [33]. Statistical analyses were performed using SPSS $^{\circledR}$ computer program (SPSS Inc., Chicago, Il, USA).

\section{RESULTS}

When the group of patients who died during the 9-years period was compared to those who survived such period, an increased cumulative quantity of smoked tobacco was the only variable significantly different (Table 1). A larger exposition to tobacco was indeed associated with an increased risk of death as those who died had a $25 \%$

Table 1. Clinical measures concerning 126 male patients with alcohol dependence according to survival status.

\begin{tabular}{|c|c|c|c|c|c|c|c|c|c|c|c|c|c|c|}
\hline & \multicolumn{7}{|c|}{ Initial group } & \multicolumn{7}{|c|}{ Followed-up group } \\
\hline & \multicolumn{3}{|c|}{$\begin{array}{l}\text { Survival status } \\
\text { missing }(\mathrm{N}=24)\end{array}$} & \multicolumn{3}{|c|}{$\begin{array}{c}\text { Survival status } \\
\text { available }(\mathrm{N}=102)\end{array}$} & \multirow[t]{2}{*}{$\mathrm{p}$} & \multicolumn{3}{|c|}{$\begin{array}{l}\text { Surviving at } 9 \text { years } \\
\qquad(\mathrm{N}=61)\end{array}$} & \multicolumn{3}{|c|}{$\begin{array}{l}\text { Deceased at } 9 \text { years } \\
\qquad(\mathrm{N}=41)\end{array}$} & \multirow[t]{2}{*}{$\mathrm{p}$} \\
\hline & mean & s.d. & $\%$ & mean & s.d. & $\%$ & & mean & s.d. & $\%$ & mean & s.d. & $\%$ & \\
\hline Age at inclusion (years) & 51.4 & 10.5 & - & 44.3 & 11.6 & - & 0.01 & 43.2 & 12.2 & - & 46.1 & 10.3 & - & 0.21 \\
\hline $\begin{array}{l}\text { Age at onset of the first alcohol dependence } \\
\text { symptom }\end{array}$ & 25.8 & 10.3 & - & 25.1 & 7.9 & - & 0.39 & 25.3 & 8.1 & - & 24.8 & 7.7 & - & 0.38 \\
\hline Mean age at onset of alcohol dependence & 33.1 & 9.2 & - & 31.8 & 7.6 & - & 0.28 & 31.2 & 7.7 & - & 32.9 & 7.5 & - & 0.15 \\
\hline Maximal alcohol consumption in 24 hours & 37.1 & 25.8 & - & 32.9 & 19.3 & - & 0.25 & 33.3 & 17.8 & - & 32.2 & 21.9 & - & 0.40 \\
\hline $\begin{array}{l}\text { Alcohol tolerance (consumption increased } \\
\text { with time) }\end{array}$ & - & - & 70.0 & - & - & 79.6 & 0.35 & - & - & 83.3 & - & - & 73.7 & 0.25 \\
\hline MAST score & 34.3 & 11.7 & - & 32.0 & 11.7 & - & 0.22 & 33.1 & 10.8 & - & 30.4 & 13.1 & - & 0.14 \\
\hline Have already smoked tobacco & - & - & 83.3 & - & - & 92.2 & 0.19 & - & - & 95.1 & - & - & 87.8 & 0.18 \\
\hline $\begin{array}{l}\text { Cumulative tobacco smoking if smoker } \\
\text { (pack years) }\end{array}$ & 24.4 & 13.3 & - & 30.6 & 16.2 & - & 0.09 & 28.0 & 15.4 & - & 34.5 & 16.9 & - & 0.05 \\
\hline DSM III-R cannabis dependence & - & - & 14.3 & - & - & 10.2 & 0.59 & - & - & 10,0 & - & - & 10.5 & 0.93 \\
\hline DSM III-R cocaine dependence & - & - & 0.0 & - & - & 6.1 & 0.24 & - & - & 4.9 & - & - & 7.7 & 0.57 \\
\hline DSM III-R dependence to psychostimulant & - & - & 0.0 & - & - & 3.1 & 0.42 & - & - & 4.9 & - & - & 0.0 & 0.16 \\
\hline DSM III-R dependence to opioïd drugs & - & - & 14.3 & - & - & 11.2 & 0.69 & - & - & 8.2 & - & - & 15.4 & 0.26 \\
\hline $\begin{array}{l}\text { Had at least one experience with a drug except } \\
\text { alcohol, tobacco or canabis }\end{array}$ & - & - & 30.0 & - & - & 25.3 & 0.66 & - & - & 21.7 & - & - & 31.4 & 0.29 \\
\hline Major depressive disorder (DSM III-R) & - & - & 11.1 & - & - & 19.4 & 0.4 & - & - & 21.4 & - & - & 16.2 & 0.53 \\
\hline Number of suicide attempt & 1.3 & 2.2 & - & 1.3 & 3.5 & - & 0.47 & 1.0 & 1.6 & - & 1.7 & 5.2 & - & 0.20 \\
\hline At least one suicide attempt & - & - & 47.6 & - & - & 36.7 & 0.35 & - & - & 40.0 & - & - & 31.6 & 0.40 \\
\hline Antisocial personnality (DSM III-R) & - & - & 28.6 & - & - & 14.3 & 0.11 & - & - & 15.0 & - & - & 13.2 & 0.80 \\
\hline Barrat impulsive score & 68.2 & 17.0 & - & 63.2 & 19.3 & - & 0.12 & 64.7 & 18.4 & - & 60.5 & 20.9 & - & 0.17 \\
\hline
\end{tabular}


increase of cumulative tobacco consumption at baseline (Table 1). This might be better explained by a longer exposition rather than the intensity of tobacco dependence, as the level of tobacco dependence was not significantly different between the two groups, with even a tendency for more severe dependence in the surviving group ( $\mathrm{p}<0.10)$. No socio-demographical and clinical characteristics of alcohol-dependence, psychiatric and addictive comorbity or impulsivness level distinguished the two groups (Table 1).

Regarding the three studied candidate genes, no significant differences were found for 5-HTTLPR and DRD2 Taq1A polymorphisms (Table 2). On the other hand, the C allele of the 5-HT1b gene was found in excess in the non-surviving population (37.2\%) compared to the surviving patients (23.8\%) $(\mathrm{OR}=1.90 ; 95 \%$ CI [1.02 - 3.52]), due to an excess of the GG genotype in the surviving group (OR $=2.40 ; 95 \%$ CI $[1.05-5.50]$ ) (Table 2). The impact of age at interview may not explain such differences, or absence of difference for the first two genes, as the average age at inclusion (initial interview) was not significantly different in the sample with or without the short allele of the 5-HTT gene $(\mathrm{t}=$
0.072, $\mathrm{p}=0.471)$, the A1 allele of the DRD2 gene $(\mathrm{t}=$ $0.718, p=0.237)$ and the $\mathrm{C}$ allele of the $5-\mathrm{HT} 1 \mathrm{~b}$ gene $(\mathrm{t}$ $=0.844, \mathrm{p}=0.200)$. It has to be mentioned that chance finding cannot be ruled out as the association between the $\mathrm{C}$ allele and the surviving status is not strong enough to be still significant after the Bonferroni correction is applied (with 3 tested genes, the required p-value could be 0.017 ).

In order to depict if the role of the $\mathrm{C}$ allele of the 5-HT1b gene may be associated with an increased mortality after 9 years through antisocial personality disorder, a logistic regression analysis was performed testing the respective role of the $\mathrm{C}$ allele (or the GG genotype), presence of antisocial personality disorder, and interaction between the gene and this trait (Table 3). As interaction might be detected even without an independent effect of a trait, the same approach was used for the short allele of the 5-HTT gene and suicidal attempts and for the A1 allele of the DRD2 gene and presence of other dependencies. No significant interaction were detected (Table 3).

Assessing if these three candidate genes could be involved in the significant role of the excess consumption

Table 2. Survival status after 9 years of 102 patients with DSM-III-R alcohol-dependence according to 3 candidate genes (serotonin receptor 5-5HT1B (G861C), serotonin transporter 5-HTT (5HTTLPR), dopamine receptor D2 (DRD2 TaqA), linical measures concerning 126 male patients with alcohol dependence according to survival status.

\begin{tabular}{|c|c|c|c|c|c|}
\hline \multirow{3}{*}{ Gene } & \multirow{3}{*}{ Polymorphisms } & \multicolumn{4}{|c|}{ Sample of patients } \\
\hline & & \multicolumn{2}{|c|}{ Surviving $N=61$} & \multicolumn{2}{|c|}{ Not surviving $N=41$} \\
\hline & & $\mathrm{n}$ & $\%$ & $\mathrm{n}$ & $\%$ \\
\hline \multirow{5}{*}{$5 \mathrm{HT} 1 \mathrm{~B}^{*, * *}$} & GG & 35 & 57.38 & 14 & 35.9 \\
\hline & GC & 23 & 37.70 & 21 & 53.85 \\
\hline & CC & 3 & 4.92 & 4 & 10.26 \\
\hline & G & 93 & 76.23 & 49 & 62.82 \\
\hline & $\mathrm{C}$ & 29 & 23.77 & 29 & 37.18 \\
\hline \multirow{5}{*}{ 5HTT } & LL & 12 & 25.00 & 13 & 37.14 \\
\hline & LS & 27 & 56.25 & 16 & 45.71 \\
\hline & SS & 9 & 18.75 & 6 & 17.14 \\
\hline & S & 45 & 46.88 & 28 & 40.00 \\
\hline & $\mathrm{L}$ & 51 & 53.13 & 42 & 60.00 \\
\hline \multirow{5}{*}{ DRD2 } & A1A1 & 36 & 59.02 & 25 & 60.98 \\
\hline & A1A2 & 23 & 37.70 & 14 & 34.15 \\
\hline & $\mathrm{A} 2 \mathrm{~A} 2$ & 2 & 3.28 & 2 & 4.88 \\
\hline & A1 & 27 & 22.13 & 18 & 21.95 \\
\hline & A2 & 95 & 77.87 & 64 & 78.05 \\
\hline
\end{tabular}

${ }^{*} \mathrm{GG}$ vs GC or CC: $\chi^{2}=4.39 ; \mathrm{df}=1 ; \mathrm{p}=0.04 ;{ }^{* *}$ Allelic frequency $\operatorname{fr}(\mathrm{G})$ vs $\operatorname{fr}(\mathrm{C}): \chi^{2}=4.15 ; \mathrm{df}=1 ; \mathrm{p}=0.04$. 
Table 3. Specific role of three candidate genes and their potentially related phenotype in the prediction of mortality after 9 years in 102 patients with alcohol dependence in a regression analysis.

\begin{tabular}{|c|c|c|c|c|}
\hline Genes & Predictive variables & Wald $\chi^{2}$ & $\mathrm{df}$ & $\mathrm{p}$ \\
\hline & Short allele & 0.117 & 1 & 0.732 \\
\hline \multirow[t]{3}{*}{ 5-HTT } & Suicidal attempt & 0.200 & 1 & 0.654 \\
\hline & Short allele ${ }^{*}$ suicidal attempt & 0.912 & 1 & 0.339 \\
\hline & $\mathrm{C}$ allele & 2.261 & 1 & 0.133 \\
\hline \multirow[t]{3}{*}{ 5-HT1b } & ASPD & 0.005 & 1 & 0.939 \\
\hline & C allele ${ }^{*}$ ASPD & 0.003 & 1 & 0.953 \\
\hline & A1 allele & 0.065 & 1 & 0.799 \\
\hline \multirow[t]{2}{*}{ DRD2 } & Other dependence & 0.077 & 1 & 0.781 \\
\hline & A1 allele ${ }^{*}$ other dependence & 0.067 & 1 & 0.780 \\
\hline
\end{tabular}

of tobacco to explain mortality, their interaction was tested, with no significant effect $(p=0.314$ for GG genotye; $\mathrm{p}=0.863$ for the short allele and $\mathrm{p}=0.186$ for the A1 allele).

\section{CONCLUSIONS}

When studying the survival status of the population of 126 male patients with alcohol dependence that we initially recruited 9 years before for genetic studies, we found that the level of tobacco consumption was the only clinical variable that was associated with an excessive mortality rate in the 102 patients we were able to analyse. For the genetic analyses, we did not observed any association between Taq1 DRD2 gene polymorphism and mortality rate at 9 years, in contrast with a previous research which had a larger sample [13]. Otherwise, the $\mathrm{C}$ allele of the 5-HT1b was found in excess in the nonsurviving group, but this vulnerability genotype was not modifying the risk of mortality through the phenotype with which it was initially associated, namely impulsivity and antisocial personality disorder. Furthermore, the detected association was not important enough to be still significant after the Bonferroni correction is applied regarding the fact that 3 genes were analysed.

The main clinical trait associated with short term risk of mortality (9 years) is therefore the cumulative consumption of tobacco. Surviving individuals smoked in average 28 pack-years compared to 35 pack-years in non-surviving individuals. The significant role of tobacco exposition is coherent with the literature indicating that smoking is one of the main co-factor explaining alcohol-related mortality [34]. This result favours the treatment of both tobacco and alcohol dependence during withdrawal processes, regarding their high comorbidity and the rapid influence on mortality of the associated tobacco dependence.
Previous studies on the 5HT1B gene in alcoholism were indeed conflicting. After the first association involving the $861 \mathrm{C}$ allele with antisocial alcoholism in a male subpopulation of frequent criminal offenders [35], negative or more complex results were also published. For example, no role of the $\mathrm{C}$ allele was detected in our cohort [27], in patients with alcohol and cocaine abuse [36], in heroin dependence [37], nor in a group of patients with a specific type of alcoholism according to Cloninger typology [38]. Without confirming 861C allelic association, a recent study performed in China detected a lower frequency of an haplotype which contains the other allele (861G) in alcohol-dependents [39]. Even more confusing, an association 5HT1B 861G allele with alcohol-dependence [40] was also found, involving antisocial personality traits-conduct disorder in patients with alcohol dependence according to another study [41].

One important limitation of our study is a limited delay of surviving evaluation, and the absence of assessment of initial medical co-morbidity. The relatively short time analysis (9 years) could explain why no other parameters were involved, even for those that were previously involved, such as alcoholism severity and presence of antisocial personality disorder [10]. Furthermore, as our sample was in average 44 years old at inclusion, the impact of psychiatric comorbidity might have been partially censored. For example, antisocial men have been shown to be at excessive risk for premature death if younger than 40 years [42].

In conclusion, although we did not identify interaction between a potentially vulnerability gene and traits associated with alcohol dependence, in our sample of 102 alcohol dependent patients, but a specific effect was detected with both tobacco consumption and a vulnerability allele of the 5-HT1b, these two factors, if truly involved, could act independently. The way the $\mathrm{C}$ allele is associ- 
ated with an increased risk of death after 9 years, in alcohol dependent patients is thus not yet detected, even if the traits that were previously associated with this allele could be excluded.

\section{REFERENCES}

[1] Banks, S.M., Pandiani, J.A., Schacht, L.M. and Gauvin, LM. (2000) Age and mortality among white male problem drinkers. Addiction, 95, 1249-1254. doi:10.1046/j.1360-0443.2000.958124911.x

[2] Smith, E.M., Cloninger, C.R. and Bradford, S. (1983) Predictors of mortality in alcoholic women: Prospective follow-up study. Alcoholism: Clinical and Experimental Research, 7, 237-243. doi:10.1111/j.1530-0277.1983.tb05449.x

[3] Jorm, A.F., Rodgers, B., Jacomb, P.A., Christensen, H., Henderson, S. and Korten, A.E. (1999) Smoking and mental health: Results from a community survey. Medical Journal of Australia, 170, 74-77.

[4] Regier, D.A., Farmer, M.E., Rae, D.S., Locke, B.Z., Keith, S.J., Judd, L.L. and Goodwin, F.K. (1990) Comorbidity of mental disorders with alcohol and other drug abuse. Results from the Epidemiologic Catchment Area (ECA) Study. Journal of the American Medical Association, 264, 2511-2518. doi:10.1001/jama.1990.03450190043026

[5] Martin, R.L., Cloninger, C.R., Guze, S.B. and Clayton, P.J. (1985) Mortality in a follow-up of 500 psychiatric outpatients. I. Total mortality. Archives of General Psychiatry, 42, 47-54. doi:10.1001/archpsyc.1985.01790240049005

[6] Eckhardt, L., Woodruff, S.I. and Elder, J.P. (1994). A Longitudinal analysis of adolescent smoking and its correlates. Journal of School Health, 64, 67-72. doi:10.1111/j.1746-1561.1994.tb06181.x

[7] Bien, T.H. and Burge, R. (1990) Smoking and drinking: A review of the literature. International Journal of the Addictions, 25, 1429-1454.

[8] DiFranza, J.R. and Guerrera, M.P. (1990) Alcoholism and smoking. Journal of Studies on Alcohol, 51, 130-135.

[9] Hartwig, W., Werner, J., Ryschich, E., Mayer, H., Schmidt, J., Gebhard, M.M., Herfarth, C. and Klar, E. (2000) Cigarette smoke enhances ethanol-induced pancreatic injury. Pancreas, 21, 272-278. doi:10.1097/00006676-200010000-00009

[10] Powell, B.J., Landon, J.F., Cantrell, P.J., Penick, E.C., Nickel, E.J., Liskow, B.I., Coddington, T.M., Campbell, J.L., Dale, T.M., Vance, M.D. and Rice, A.S. (1998) Prediction of drinking outcomes for male alcoholics after 10 to 14 years. Alcoholism: Clinical and Experimental Research, 22, 559-566. doi:10.1111/j.1530-0277.1998.tb04293.x

[11] Martin, R.L., Cloninger, C.R., Guze, S.B. and Clayton, P.J. (1985) Mortality in a follow-up of 500 psychiatric outpatients. II. Cause-specific mortality. Archives of General Psychiatry, 42, 58-66.

\section{doi:10.1001/archpsyc.1985.01790240060006}

[12] Fridell, M. and Hesse, M. (2006) Psychiatric severity and mortality in substance abusers: A 15-year follow-up of drug users. Addictive Behaviors, 31, 559-565. doi:10.1016/j.addbeh.2005.05.036

[13] Berggren, U., Fahlke, C., Berglund, K.J., Wadell, K., Zetterberg, H., Blennow, K., Thelle, D. and Balldin, J. (2010) Dopamine D2 receptor genotype is associated with increased mortality at a 10-year follow-up of alcoholdependent individuals. Alcohol and Alcoholism, 45, 1-5. doi:10.1093/alcalc/agp041

[14] Gorwood, P., Wohl, M., Le Strat, Y. and Rouillon, F. (2007) Gene-environment interactions in addictive disorders: Epidemiological and methodological aspects. Comptes Rendus Biologies, 330, 329-338. doi:10.1016/j.crvi.2007.02.017

[15] García-Bañuelos, J., Panduro, A., Gordillo-Bastidas, D., Gordillo-Bastidas, E., Muñoz-Valle, J.F., Gurrola-Díaz, C.M., Sánchez-Enríquez, S., Ruiz-Madrigal, B. and Bastidas-Ramírez, B.E. (2011) Genetic polymorphisms of genes coding to alcohol-metabolizing enzymes in western Mexicans: Association of CYP2E1*c2/CYP2E1*5B allele with cirrhosis and liver function. Alcoholism: Clinical and Experimental Research, 36, 425-431.

[16] Grove, J., Brown, A.S., Daly, A.K., Bassendine, M.F., James, O.F. and Day, C.P. (1998) The RsaI polymerphism of CYP2E1 and susceptibility to alcoholic liver disease in Caucasians: Effect on age of presentation and dependence on alcohol dehydrogenase genotype. Pharmacogenetics, 8, 335-342. doi:10.1097/00008571-199808000-00007

[17] Chen, J., Giovannucci, E.L. and Hunter, D.J. (1999) MTHFR polymorphism, methyl-replete diets and the risk of colorectal carcinoma and adenoma among U.S. men and women: An example of gene-environment interactions in colorectal tumorigenesis. Journal of Nutrition, 129, 560S-564S.

[18] Lussier-Cacan, S., Bolduc, A., Xhignesse, M., Niyonsenga, T. and Sing, C.F. (2002) Impact of alcohol intake on measures of lipid metabolism depends on context defined by gender, body mass index, cigarette smoking, and apolipoprotein Egenotype. Arteriosclerosis, Thrombosis, and Vascular Biology, 22, 824-831. doi:10.1161/01.ATV.0000014589.22121.6C

[19] Koopmans, J.R., Slutske, W.S., Heath, A.C., Neale, M.C. and Boomsma, D.I. (1999) The genetics of smoking initiation and quantity smoked in Dutch adolescent and young adult twins. Behavior Genetics, 29, 383-393. doi:10.1023/A:1021618719735

[20] Gorwood, P., Schumann, G., Treutlein, J. and Adès, J. (2006) Pharmacogenetics of alcohol dependence. In: Gorwood, P. and Hamon, M. Eds., Psychopharmacogenetics, Springer Inc., 177-202. doi:10.1007/0-387-34577-2_7

[21] Hinckers, A.S., Laucht, M., Schmidt, M.H., Mann, K.F., Schumann, G., Schuckit, M.A. and Heinz, A. (2006) Low level of response to alcohol as associated with serotonin transporter genotype and high alcohol intake in adolescents. Biological Psychiatry, 60, 282-287. doi:10.1016/j.biopsych.2005.12.009 
[22] Pianezza, M.L., Sellers, E.M. and Tyndale, R.F. (1998) Nicotine metabolism defect reduces smoking, Nature, 393, 750. doi:10.1038/31623

[23] Young, S.E., Friedman, N.P., Miyake, A., Willcutt, E.G., Corley, R.P., Haberstick, B.C. and Hewitt, J.K. (2009) Behavioral disinhibition: Liability for externalizing spectrum disorders and its genetic and environmental relation to response inhibition across adolescence. Journal of $A b$ normal Psychology, 118, 117-130. doi:10.1037/a0014657

[24] Gorwood, P., Batel, P., Gouya, L., Courtois, F. and Feingold, J. (2000) Reappraisal of the association between the DRD2 gene, alcoholism and addiction. European Psychiatry, 15, 90-96. doi:10.1016/S0924-9338(00)00207-8

[25] Blum, K., Braverman, E.R., Holder, J.M., Lubar, J.F., Monastra, V.J., Miller, D., Lubar, J.O., Chen, T.J. and Comings, D.E. (2000) Reward deficiency syndrome: A biogenetic model for the diagnosis and treatment of impulsive, addictive, and compulsive behaviors. Journal of Psychoactive Drugs, 32, 1-112.

[26] Blum, K., Chen, A.L., Braverman, E.R., Comings, D.E., Chen, T.J., Arcuri, V., Blum, S.H., Downs, B.W., Waite, R.L., Notaro, A., Lubar, J., Williams, L., Prihoda, T.J., Palomo, T. and Oscar-Berman, M. (2008) Attention-deficit-hyperactivity disorder and reward deficiency syndrome. Neuropsychiatric Disease and Treatment, 4, 893918.

[27] Gorwood, P., Aissi, F., Batel, P., Ades, J., Cohen-Salmon, C., Hamon, M., Boni, C. and Lanfumey, L. (2002) Reappraisal of the serotonin 5-HT(1B) receptor gene in alcoholism: Of mice and men. Brain Research Bulletin, 57, 103-107. doi:10.1016/S0361-9230(01)00641-4

[28] Gorwood, P., Batel P, Ades J, Hamon M. and Boni C. (2000) Serotonin transporter gene polymorphisms, alcoholism, and suicidal behavior. Biological Psychiatry, 48, 259-264. doi:10.1016/S0006-3223(00)00840-4

[29] Nurnberger, J.I., Blehar, M.C., Kaufmann, C.A., YorkCooler, C., Simpson, S.G., Harkavy-Friedman, J., et al. (1994) Diagnostic interview for genetic studies: Rational, unique features, and training. Archives of General Psychiatry, 51, 849-862. doi:10.1001/archpsyc.1994.03950110009002

[30] Grandy, D.K., Zhang, Y. and Civelli, O. (1993) PCR detection of the TaqA RFLP at the DRD2 locus. Human Molecular Genetics, 2, 2197. doi:10.1093/hmg/2.12.2197-a

[31] Heils, A., Teufel, A., Petri, S., Stober, G., Riederer, P., Bengel, D. and Lesch, K.P. (1996) Allelic variation of human serotonin transporter gene expression. Journal of Neurochemistry, 66, 2621-2624. doi:10.1046/j.1471-4159.1996.66062621.x

[32] Lappalainen, J., Dean, M., Charbonneau, L., Virkkunen, M., Linnoila, M. and Goldman, D. (1995) Mapping of the serotonin 5-HT1D autoreceptor gene on chromosome 6 and direct analysis for sequence variants. American Journal of Medical Genetics, 60, 157-161.

\section{doi:10.1002/ajmg.1320600214}

[33] Hosmer, D.W. and Lemeshow, S. (1980) A goodnessof-for test for the multiple logistic regression. Communications in Statistics, A10, 1043-1069. doi:10.1080/03610928008827941

[34] Kozlowski, L.T. and Ferrence, R.G. (1990) Statistical control in research on alcohol and tobacco: An example from research on alcohol and mortality. British Journal of Addiction, 85, 271-278. doi:10.1111/j.1360-0443.1990.tb03083.x

[35] Lappalainen, J., Long, J.C., Eggert, M., Ozaki, N., Robin, R.W., Brown, G.L., Naukkarinen, H., Virkkunen, M., Linnoila, M. and Goldman, D. (1998) Linkage of antisocial alcoholism to the serotonin 5-HT1B receptor gene in 2 populations. Archives of General Psychiatry, 55, 989994. doi:10.1001/archpsyc.55.11.989

[36] Cigler, T., LaForge, K.S., McHugh, P.F., Kapadia, S.U., Leal, S.M. and Kreek, M.J. (2001) Novel and previously reported single-nucleotide polymorphisms in the human 5-HT(1B) receptor gene: No association with cocaine or alcohol abuse or dependence. American Journal of Medical Genetics, 5, 489-497. doi:10.1002/ajmg.1473

[37] Proudnikov, D., LaForge, K.S., Hofflich, H., Levenstien, M., Gordon, D., Barral, S., Ott, J. and Kreek, M.J. (2006) Association analysis of polymorphisms in serotonin $1 \mathrm{~B}$ receptor (HTR1B) gene with heroin addiction: A comparison of molecular and statistically estimated haplotypes. Pharmacogenetics and Genomics, 16, 25-36. doi:10.1097/01.fpc.0000182782.87932.d6

[38] Sinha, R., Cloninger, C.R. and Parsian, A. (2003) Linkage disequilibrium and haplotype analysis between serotonin receptor $1 \mathrm{~B}$ gene variations and subtypes of alcoholism. American Journal of Medical Genetics Part B: Neuropsychiatric Genetics, 121, 83-88. doi:10.1002/ajmg.b.20064

[39] Cao, J.X., Hu, J., Ye, X.M., Xia, Y., Haile, C.A., Kosten, T.R. and Zhang, X.Y. (2011) Association between the 5-HTR1B gene polymorphisms and alcohol dependence in a Han Chinese population. Brain Research, 1376, 1-9. doi:10.1016/j.brainres.2010.12.039

[40] Fehr, C., Grintschuk, N., Szegedi, A., Anghelescu, I., Klawe, C., Singer, P., Hiemke, C. and Dahmen, N. (2000) The HTR1B 861G $>$ C receptor polymorphism among patients suffering from alcoholism, major depression, anxiety disorders and narcolepsy. Psychiatry Research, 97, 110. doi:10.1016/S0165-1781(00)00215-8

[41] Soyka, M., Preuss, U.W., Koller, G., Zill, P. and Bondy, B. (2004) Association of 5-HT1B receptor gene and antisocial behavior in alcoholism. Journal of Neural Transmission, 111, 101-109. doi:10.1007/s00702-003-0064-0

[42] Black, D.W., Baumgard, C.H., Bell, S.E. and Kao, C. (1996) Death rates in 71 men with antisocial personality disorder. A comparison with general population mortality. Psychosomatics, 37, 131-136. 